Int. J. Dev. Biol. 57: 185-195 (2013)

doi: $10.1387 / \mathrm{ijdb} .130068 \mathrm{ja}$

\title{
The spermatogonial stem cell niche in testicular germ cell tumors
}

\author{
UNAI SILVÁN ${ }^{1, \#}$, ALEJANDRO DÍEZ-TORRE², PABLO MORENO ${ }^{1}$, JON ARLUZEA ${ }^{1,2}$, \\ RICARDO ANDRADE ${ }^{2}$, MARGARITA SILIÓ ${ }^{1}$ and JUAN ARÉCHAGA ${ }^{*, 1,2}$ \\ ${ }^{1}$ Laboratory of Stem Cells, Development and Cancer, Department of Cell Biology and Histology and ${ }^{2}$ Analytical and \\ High Resolution Biomedical Microscopy Core Facility, University of the Basque Country, Vizcaya, Spain
}

\begin{abstract}
Spermatogonial stem cells (SSCs) are pluripotent elements found in the adult seminiferous epithelium between Sertoli cells and a basal lamina which covers the multilayered external wall of peritubular myoid cells. The microenvironment of this pluripotent stem cell niche creates the complex and dynamic system that is necessary for the initiation of spermatogenesis, but this system also contains factors which can potentially collaborate in the progression of testicular germ cell tumors (TGCTs). In this review, we summarize our current knowledge about some important structural and molecular features related to the SSC niche, including growth factors, adhesion molecules, extracellular matrix, mechanical stress and vascularization. We discuss their possible collaborative effects on the generation and progression of TGCTs, which are a type of cancer representing the most frequent neoplasia among young men and whose incidence has grown very quickly during the past decades in North America and Europe. In this regard, a better understanding of the pluripotent stem cell niche where these malignancies arise will provide further insights into the origin of TGCTs and the mechanisms underlying their growth and invasion of adjacent and distant tissues.
\end{abstract}

KEY WORDS: testis, spermatogonia, germ cell tumor, embryonal carcinoma, teratocarcinoma, cancer stem cell

\section{Introduction}

Stem cells (SC) perpetuation is one of the main factors for the maintenance of tissue homeostasis in mammals and other vertebrates. During embryonic development SC give rise to a variety of tissues as they acquire a commitment toward a particular cell lineage, producing differentiated cell types and preserving a self-renewing population of undifferentiated cells. The plasticity of the resulting stem cell reservoir in adult tissues is variable. In most of the cases, these cells are committed to differentiate into organ-specific cell types (unipotent SC), while in other cases, like in the hematopoietic cell lineages (multipotent SC) or the germ line (pluripotent SC) give rise to a number of cell types under the appropriate conditions. The microenvironment that regulates the plasticity and fate of SC is known as "stem cell niche" (SC niche), and is composed of a mixture of chemical and physical signals provided by a number of related cells.

The concept of the SC niche was first coined in relation with the hematopoietic SC microenvironment at the bone marrow (Schofield,
1978). Since then, many other tissue-specific SC niches have been identified and characterized, including that of spermatogonial SCs. Research on SC niches has shown that microenvironment plays a key role on SC fate and that the dysfunction of any of its components can drive to the loss of tissue homeostasis and subsequently to different pathological conditions, from degenerative diseases to cancer (Blagoev, 2011; Bonafè et al., 2012). Interest-

\footnotetext{
Abbreviations used in this paper: CAM, cell adhesion molecule; CIS, carcinoma in situ; C.SG, cancer stem cell; CSF-1, colony stimulating factor one; Csfl r, CSF-1 receptor; E-cadherin, epithelial cadherin; EC, embryonal carcinoma; EGM, extracellular matrix; EGF, epithelial growth factor; ES cell, embryonic stem cell; FGF2, fibroblast growth factor 2; GCT, germ cell tumor; GDNF, glial-derived neurotrophic factor; GFR, GDNF family receptor; HIF-1, hypoxia inducible factor one; IF, intermediate filament; LIF, leukemia inhibitory factor; MCP-1, monocyte chemoattractant protein one; MT, microtubule; N-cadherin, neural-cadherin; NGF, nerve growth factor; PIGF, placental-like growth factor; PM cell, peritubular myoid cell; SMA, smooth muscle actin; SSC, spermatogonial stem cell; TGCT, testicular germ cell tumor; VE-cadherin, vascular-endothelial cadherin.
}

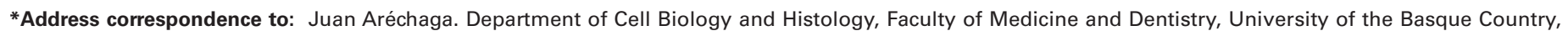
48940 Leioa, Vizcaya, Spain. Fax: +34-94-601-3266. e-mail: juan.arechaga@ehu.es

\#Present address: ETH Zürich, Institute for Biomechanichs, and University of Zürich, Balgrist university Hospital, Zürich, Switzerland.

Final, author-corrected PDF published online: 5 June 2013

ISSN: Online 1696-3547, Print 0214-6282

(C) 2013 UBC Press

Printed in Spain 

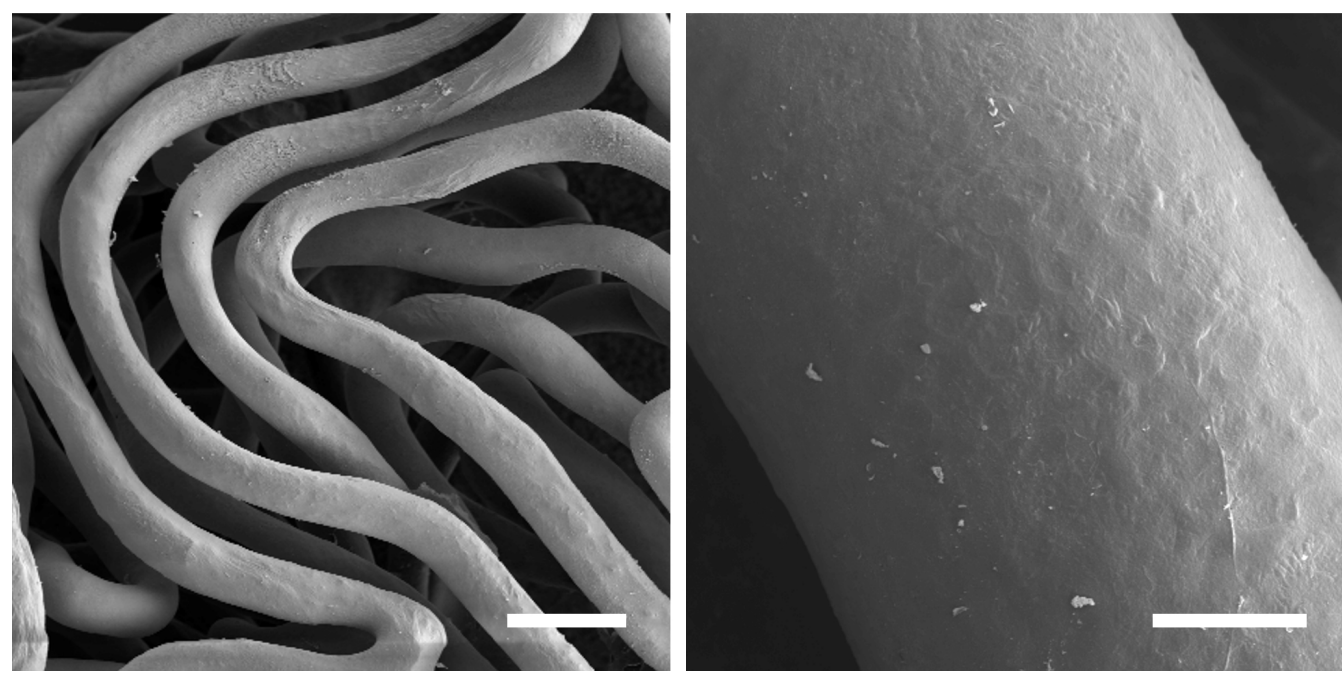

Fig. 1. Corrosion casts of the seminiferous tubules network. (A) Scanning electron micrograph of the seminiferous tubules of a murine testis filled with a polymerizable resin. For better observation tissues have been chemically digested and removed. (B) At higher magnification imprints left by the cells on the surface of the resin can be seen. Scale bars represent $250 \mu \mathrm{m}$ in (A) and $25 \mu \mathrm{m}$ in (B). For more details we refer the reader to Silvan \& Arechaga, 2012.

ingly enough, it has been shown that the normal function of aged SC niches can be recovered when they are exposed to systemic factors from young individuals (Conboy et al., 2005); this points to the manipulation of SC niches as a potential therapeutic strategy for diseases associated with SC dysfunction.

Among the identified niches, the one corresponding to spermatogonia results especially interesting since spermatogenesis is indispensable for the persistence of species and any disturbance of SSC microenvironment can lead to the loss or reduction of fertility (Oatley and Brinster, 2008). Moreover, SSC niche could play a central role in the development of some testicular germ cell tumors (TGCTs), whose origin has been proposed to be the differentiation arrest in male primordial germ cells (PGCs), the precursors of the male germ line, during fetal development (Hoei-Hansen etal., 2005).

Germ cell tumors represent about $95 \%$ of testicular neoplasias and their rate of occurrence has suffered a significant increase in the last 50 years; nowadays this type of cancer is even the most common malignancy among young men. Human germ cell tumors can be arranged in five main groups on the basis of their embryological origin and histology, according to the useful classification of Oosterhuis and Looijenga (2005). Type I GCTs are represented by the teratomas and yolk-sac carcinomas, which appear at the gonads and the midline body regions of neonates and infants. Type II TGCTs includes testicular seminomatous and non-seminomatous, which are characteristic of middle age adults or young men respectively. Type III GCTs are the spermatocytic seminomas, found mainly in elderly men. Type IV GCTs are the ovarian dermoid cysts. Finally, Type $\mathrm{V}$ the hydatidiform mole of the uterus that may lead to a choriocarcinoma. The Type I/ GC seminomatous tumors are poorly invasive and present a homogeneous histology with the presence of gonocyte-like cells whereas the Type // GC non-seminomatous tumors, on the contrary, show a much more aggressive phenotype with a heterogeneous histology, where a wide variety of differentiated tissues can be found, mixed with the cancer SC population known as embryonal carcinoma (EC). These EC cells express a pattern of pluripotency markers similar to that of the embryonic stem (ES) cells. Interestingly, it has been established that Type II TGCTs derive from the so-called carcinoma in situ (CIS) of the testis, a cell type that shares many features with ES cells. These particular cells, larger than normal spermatogonia and with big glycogen vacuoles are usually located in a single row underlying the basement membrane of seminiferous tubules. The CIS cells are thought to develop during development directly from PGCs that have suffered an impaired differentiation and stay arrested and quiescent in the seminiferous tubuli until puberty, when they start to proliferate and give rise to any of the type II TGCTs (Rajpert-De Meyts, 2006).

The SSC niche is located at the basal layer of the seminiferous epithelium and is composed mainly by Sertoli cells and a basal lamina covered by the so-called peritubular myoid (PM) cells (Fig. 1). Leydig cells, a few stroma cells of mesenquimal origin, a soft extracellular matrix and lymphatic and blood capillaries occupy the interstitial space among seminiferous tubules (Figs. 2 and 3). All these components contribute together to create the SSC microenvironment, which regulates many aspects of stem cell functions, such as self-renewal, differentiation and apoptosis (Oatley and Brinster, 2012).

SSC self-renewal is necessary to maintain a stem cell pool with the ability to produce differentiating spermatogonia and the balance between self-renewal and differentiation has to be finely regulated to sustain spermatogenesis at optimal levels. Research on the SSC niche in mouse models has shed light on the growth factors that regulate SSC fate and testicular cell types that secrete them. Moreover, SSCs express adhesion molecules that mediate their response to the microenvironment and regulate stem cell homing to the niche. Some of the TGCT microenvironment characteristics, such as changes in the ECM or apoptosis-related growth factors, have been already described and could give a clue about the alterations of the SSC that might be involved in TGCT origin or progression (Díez-Torre et al., 2010; Timmer et al., 1994). Moreover, several risk factors have been identified in relation with TGCT development, such as undescended testis, contralateral testicular GCT, familial testis cancer or environmental toxics but, so far, the way these factors affect the function of the SSC niche, and thus the testicular homeostasis, is still unknown. Given that Type II TGCTs arise from abnormal SSC (CIS cells) and the importance of the SSC niche in regulating the normal or pathological behavior of these cells, this review will address the current knowledge about SSC microenvironment, its role in TGCT development and its suitability as a potential therapeutic target. 


\section{Growth factors}

Research on SSC niche has revealed that virtually all the somatic cell populations of mammalian testes participate at some level in the biology of SSC microenvironment and, subsequently, in regulation of SSC fate, by means of self-renewal or differentiation signals. Among testicular somatic cells, Sertoli cells are the only somatic cell type found inside the seminiferous tubules and those that maintain the closest relationship with the germ line. For this reason, these cells might be the key regulators of the SSC niche. In fact, Sertoli cells have been identified as the main source of two growth factors that play a critical role in the regulation of spermatogonia self-renewal, these are the glial cell line-derived neurotrophic factor (GDNF) and the fibroblast growth factor 2 (FGF2) (Mullaney and Skinner, 1992; Tadokoro et al., 2002). In the last decades, SSC isolation, culture and transplantation techniques allowed the characterization of these factors in the establishment of the SSC niche.

The search for the more suitable conditions for SSC culture in vitro demonstrated that GDNF plays an essential role in maintaining SSC self-renewal. It has been shown that supplementation with GDNF favors survival of SSC in vitro, resulting in an increase of the number of cells with the ability of re-establishing spermatogenesis after transplantation (Nagano et al., 2003). Moreover, it has been reported that the presence of GDNF is absolutely necessary for long-term maintenance in vitro of SSCs from different species. Interestingly, in many cases GDNF is not enough to maintain long-term SSC self-renewal in vitro and a second growth factor is needed, such as FGF-2 or epithelial growth factor (EGF) (Kubota et al., 2004). Nevertheless, even though FGF2 and EGF induce proliferation of SSCs in the presence of GDNF, they are not specific for self-renewal. Indeed, they promote both expansion of SSC number and production of non-stem cell progenitor spermatogonia in vitro (Lee et al., 2007). Moreover, GDNF seems to induce survival and proliferation in several types of undifferentiated spermatogonia and not only in SSCs. In fact, the GDNF receptor complex, constituted by c-RET and GDNF family receptor 1 (GFR1) has been localized in different spermatogonia subtypes depending on the developmental stage of the testis (Suzuki et al., 2009). Thus, the specific regulation of SSC fate after division might be achieved by another unknown growth factor.

The research on SSC niche has provided a huge body of evidence to support the role of GDNF in maintaining the testis homeostasis in vivo. It has been reported that GDNF deficient mice suffer fertility problems, with absence of germ cells in most of the seminiferous tubules. In contrast, mutant mice over-expressing GDNF showed an accumulation of undifferentiated spermatogonia and a high incidence of germ cell tumors that mimic human seminomas (Meng et al., 2000). This result suggests that GDNF deregulation could be involved in the origin of TGCTs. In fact, GFR1 over-expression has been recently reported in CIS cells and in both intratubular and invasive seminomas in humans. In addition, it has been also demonstrated that GDNF enhances motility and invasive behavior of seminoma cells in vitro (Ferranti et al., 2012). Interestingly enough, the other co-receptor of GDNF, c-RET, seems to remain unaltered in TGCTs, since overexpression or mutations in these genes have not been detected (Ferranti et al., 2012). The relation of GDNF over-expression with carcinoma cell migration and invasion had been previously described in several tumor types, such as gliomas (Wan and Too, 2010), pancreatic cancer (Cavel et al., 2012), chondrosarcoma (Su et al., 2009), and colorectal cancer (Furuta et al., 2007).

Analysis of the gene expression profiles of murine undifferentiated spermatogonia have shown a high expression of the gene for the colony stimulating factor 1 receptor (Csf1r), what points to its ligand, CSF-1, as an important regulator of spermatogonial progenitor self-renewal (Oatley et al., 2009). Interestingly, when CSF-1 is added to cultures of mouse undifferentiated spermatogonia supplemented with GDNF and FGF2, the efficiency of the re-establishment of spermatogenesis after transplantation is significantly increased, indicating a better conservation of SSC features in culture (Oatley et al., 2009). Given that this result is not related with an augmentation of spermatogonia proliferation, it can be concluded that CSF-1 acts specifically on SSCS and that
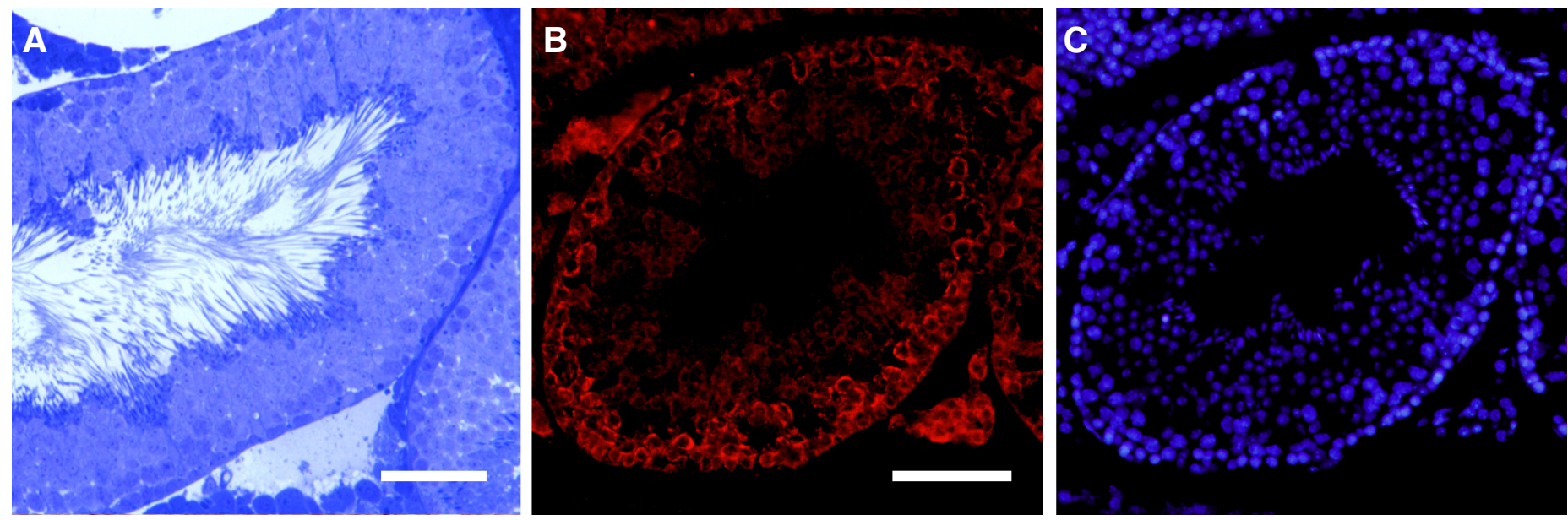

Fig. 2.The spermatogonia stem cell niche. (A) In an ultrathin section of a murine seminiferous tubule stained with Toluidine blue, the cells that conform the germinal epithelium can be seen, particularly germ cells at different stages of differentiation, and Sertoli cells. In the lumen of the seminiferous tubule, the tails of the differentiated spermatozoa can be observed. (B) Immunofluorescence using an anti-cKit primary antibody reveals the existence of this membrane receptor in spermatogonia (basal region of the epithelium) and in Leydig cells, with its presence in more differentiated germ cells being dramatically reduced. (C) DAPI staining. Scale bars represent $25 \mu \mathrm{m}$ in $(A)$ and $40 \mu \mathrm{m}$ in $(B, C)$ 
its effect is due to the predominance of self-renewal signals over those that lead to the production of other spermatogonia progenitors. Thus, CSF-1 has been the first identified specific regulator of self-renewal in the SSC niche and, despite of its important role in the regulation of the SSC function, the relation of this factor with the TGCTs has not been analyzed yet. Nevertheless, its activity as regulator of tumor-associated macrophages motility has been found to promote tumor malignancy in other tumor types, including glioblastoma (Coniglio et al., 2012) and pancreatic cancer (Pyonteck et al., 2012). The expression of CSF-1 in the testis is localized to the interstitial space between seminiferous tubules, being secreted by Leydig cells and PM cells but not Sertoli cells (Oatley et al., 2009). The fact that cell populations placed out of the physical limits of seminiferous tubules participate in the regulation of the SSC functions could be unexpected, since they do not have a direct contact with the germ cells. Yet, a number of studies have established that spermatogenesis is regulated through a crosscommunication between Sertoli and Leydig cells. Thus, Leydig and myoid cells could participate in the creation of the SSC niche through their interaction with Sertoli cells.

A recent study suggests that the participation of peritubular myoid cells to the SSC niche could be independent of Sertoli cells, since they also secrete GDNF in human testis (Spinnler et al., 2010). Until few years ago, the PM cell function was thought to be limited to the contractile activity that drives spermatozoa towards the rete testis, but recent observations have shown that these cells are also directly involved in male gonad development and maintenance of spermatogenesis (Schell et al., 2008). Furthermore, their localization in the proximity of the CIS cells and its mentioned function as regulators of the SSC niche suggest that PM cells could play a key role in the origin and progression of TGCTs, probably as part of the tumor reactive stroma in response to CIS-derived signals (Díez-Torre et al., 2011). Among the secretory products of PM cells, several growth factors have been identified, including nerve growth factor (NGF), monocyte chemoattractant protein-1 (MCP-1) and inflammatory interleukins, such as IL-6 (Schell et al., 2008). The secretory activity of PM cells is complexly regulated by other components of the testicular microenvironment. Thus, alterations of this microenvironment, such as those originated by cancer cell-derived factors, may lead to phenotypic changes in PM cells that contribute to tumor growth, invasion and metastasis. A similar effect has been described for the reactive stroma of other tumors, where tumor-associated myofibroblast, which share many phenotypic features with PM cells, play a capital role (Díez-Torre et al., 2004). Indeed, some of the growth factors secreted by the PM cells are frequently over-expressed in the reactive stroma of different neoplasias and have been related with poor prognosis. MCP-1, for example, is a key mediator of acute inflammation that attracts and activates macrophages (Fujimoto et al., 2009). Interestingly, it has been reported that macrophage infiltration correlates with angiogenesis and poor prognosis in breast carcinoma and that the treatment of mice bearing human breast cancer xenografts with MCP-1 neutralizing antibodies resulted in a significant reduction of macrophage recruitment, together with inhibited angiogenesis and tumor growth (Fujimoto et al., 2009). It is worth to mention that the removal of macrophages in mice by a homozygous null mutation of the gene that encodes CSF-1, a key regulator of SSC self-renewal that is also involved in the macrophage function, leads to a significant reduction of tumor growth rate and metastasis in these animals (Condeelis and Pollard, 2006).

Together with GDNF and CSF-1, several studies have reported that leukemia inhibitory factor (LIF) and insulin-like growth factor I (IGF-I) could be also involved in the regulation of SSC survival and self-renewal (Kubota et al., 2004; Kanatsu-Shinohara et al., 2007; Fig. 3). It has been observed, for example, that the supplementation of cultures of undifferentiated spermatogonia with IGF-I, GDNF and FGF2 produces a threefold increase in the SSC content with respect to IGF-I free cultures (Kubota et al., 2004). However, it is still unclear if the effect of IGF-I is specific to SSCs or affects to the rest of undifferentiated spermatogonia subtypes. In human testis, IGF-I is secreted by most cells, including Sertoli cells, but also by Leydig, PM cells and some germ cells (Vannelli et al., 1988). This factor has been reported to be involved in the development of the embryonic mouse testis, in the regulation of testosterone production, and in spermatogenesis (Froment et al., 2007). Interestingly, IGF-I has also been identified as a key regulator of the SDF-1/CXCR4 signalling pathway, whose function is necessary for the proper migration of PGC (Schlueter et al., 2007) and has been associated with the metastatic pattern of several carcinomas, including TGCTs. Indeed, TGCTs exhibit an outstanding conserved pattern of metastases to organs that express high levels of SDF-1, such as lymph nodes, lungs and bone; resembling patterns observed in other CXCR4 over-expressing cancers. Previous studies on the expression pattern of IGF system members have shown that IGF-I and IGFBP-5 are highly expressed in CIS cells and that this co-expression could be related with the transition from CIS to intratubular TGCTs by means of a proliferative effect (Drescher et al., 1997). IGF-I signaling has been also related with the repression of differentiation-related genes. In fact, Leydig cell-derived IGF-I mediates the maintenance of spermatogonial stem cell pluripotency and confers on them a PGC-like phenotype through PI3K pathway (Huang et al., 2009). Moreover, IGF-I signaling mediates the upregulation of MMP-2 and MT1-MMP, two proteases involved in matrix degradation and directional cell migration that are usually involved in the formation of metastases.

Taken all the mentioned findings together, it becomes clear that changes in the growth factor combination that constitute the SSC niche could be involved in the origin of TGCTs or contribute to the transition from testis CIS to invasive germ cell tumors. Thus, the re-establishment of the balance between self-renewal, proliferation and differentiation signals in the spermatogonial microenvironment could be a useful approach in the search for new therapies against these malignancies.

\section{Cell adhesion molecules}

Cells adhesion molecules (CAMs) are a large group of membrane proteins that belong to different families, including cadherins, integrins, selectins, and members of the immunoglobulin superfamily. These proteins, which can be classified into two large categories, cell-matrix and cell-cell adhesion proteins, participate in the structural organization of tissues and in the signal transduction into the cell. In the seminiferous epithelium and interstitial tissue of the testis, adhesion molecules have been reported to play a role in differentiation and self-renewal of the spermatogonial stem cells. In addition, their implication in processes such as adhesion, migration, invasion, growth, proliferation and apoptosis in cancer has received increased attention during the last years (Wong et 

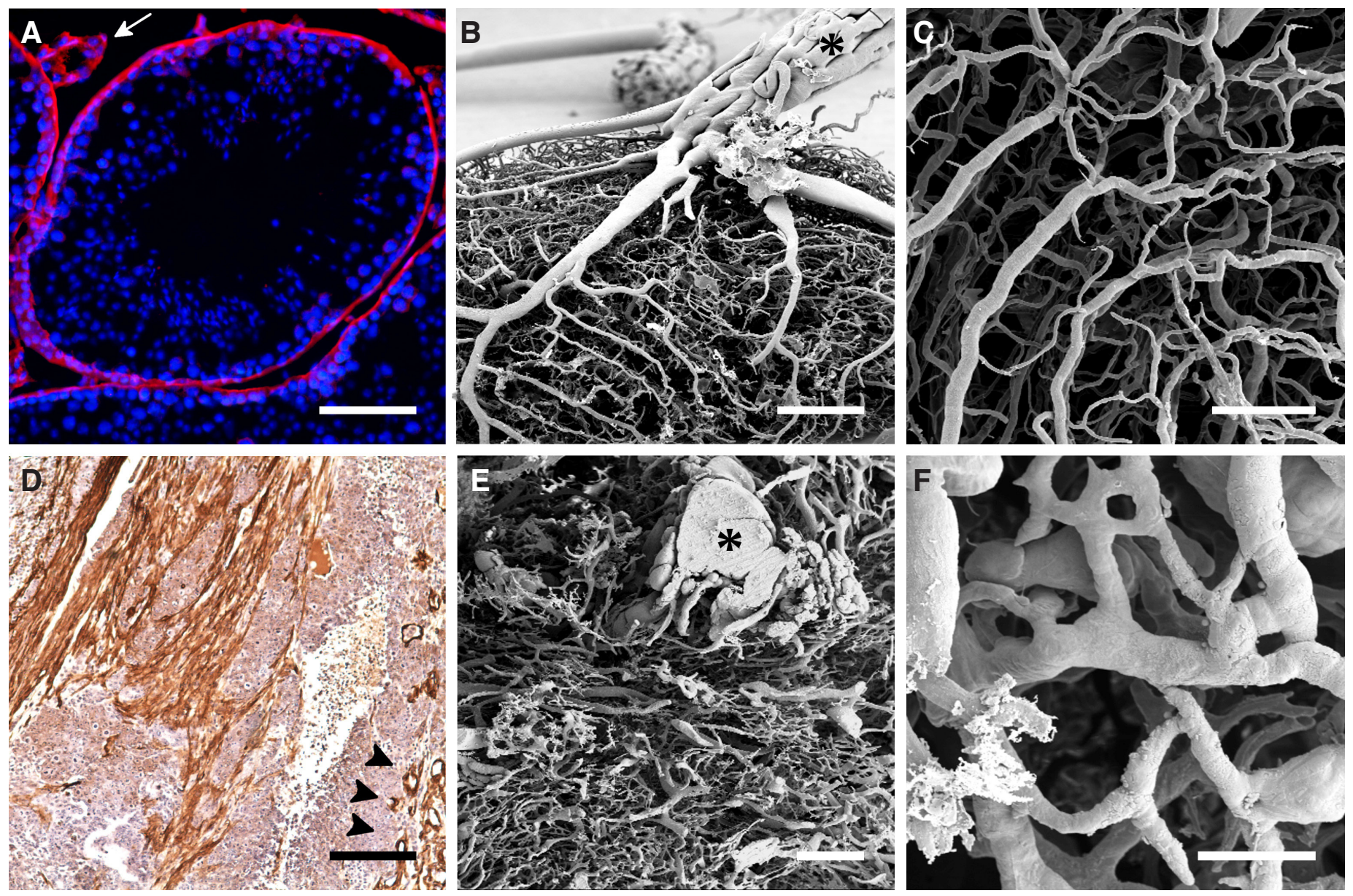

Fig. 3. Peritubular myoid (PM) cells / myofibroblasts and vascularization of the murine testis and of experimental TGCTs after ES cell transplantation into the seminiferous tubules. (A) Smooth muscle actin expression (in red) is restricted to the peritubular myoid cells and to the smooth muscle cells surrounding blood vessels (arrow); DAPI nuclear staining (blue). (B) Corrosion casting of the vascular system in the murine testis reveals the blood supply of the testis (asterisk). The arterial blood penetrates the testis surrounded by the spermatic veins (pampiniform plexus) to cool it. (C) At higher magnification, the regular organization of the testicular capillaries, that run parallel to the seminiferous tubules, can be seen. (D) Experimental TGCT myofibroblasts expressing $\alpha$-actin and forming thick layers that enclose nests of tumor cells. Extensive angiogenic capillaires can also be recognized (arrowheads). (E) In the same tumors, the regular vessel architecture of the testis is completely lost in a tangle of irregular neocapillaries, as observed in this vascular corrosion cast. However, bigger sized vessel can still be recognized (asterisk). (F) Higher magnification imaging reveals the pathological morphology of tumor vessels, with irregular sizes and frequent blind-endings, architectures incompatible with the efficient blood flow and oxygenation of the tissues. Scale bars represent $40 \mu \mathrm{m}(A) ; 600 \mu \mathrm{m}(B, E) ; 200 \mu \mathrm{m}(C, D)$ and $100 \mu \mathrm{m}$ (F).

\section{al., 2012).}

The integrin family is composed by $\alpha$ - and $\beta$ - subunits that combine into a large number of alternative dimers. At least 24 different of them have been described so far. The subunit composition of the dimers dictates their properties and functions in the integrity of the tissues through cell-cell contacts and binding of the cell to the ECM. Integrins are also involved in cell signaling related with cell death, proliferation and migration in processes such as embryonic development, homeostasis and immune response (Clifford et al., 2012).

Analysis of the expression pattern of integrins in testis containing intratubular germ cell neoplasias revealed an increased expression of $\alpha 3, \alpha 6$, and $\beta 1$ integrin subunits in Sertoli cells, but also in malignant cells. However, progression to invasive seminoma was found associated with loss of $\alpha 3$ integrin subunit expression by tumor cells (Timmer et al., 1994). Histological analysis of teratomas induced by normal and $\beta 1$-null ES cells has revealed a role of this subunit in tumor vascularization. Besides significant smaller size, tumors lacking $\beta 1$ integrin showed impaired vascularization (Bloch et al., 1997). Similarly, teratocarcinomas derived from $\alpha 5$-null ES cells showed decreased vessel area, being however, some of the injected cells able to differentiate into endothelial cells (Taverna and Hynes, 2001). Since tumors derived from $\beta 1$-null ES cells contained significantly lower number of host derived stromal cells, it is likely that this integrin is related with the vasculogenic process from host-derived endothelial precursors. However, a second vasculogenic mechanism in which transplanted ES cells differentiate into endothelial cells is as well possible (Silván et al., 2009b), even in the $\alpha 5$-null tumors (Taverna and Hynes, 2001). In fact, the $\alpha 5$ subunit has been reported to participate in the remodelling of the embryonic vascular system in a process that might resemble TGCT vascularization.

In other tumor types, the heterodimer formed by the $\alpha 5$ with the $\beta 1$ integrin subunits appears down-regulated. For example, 
in prostate cancer cells, reduced expression of $\alpha 5 \beta 1$ causes the disruption of matrix assemblage and, thus, facilitates cell detachment and subsequent invasion (Jia et al., 2012). Although the loss of cell-cell and cell-matrix contacts is necessary for the tumor cells to metastasize, the integrin expression pattern as well dictates their extravasation at specific sites. For example, cancer cells of prostatic origin express functional $\alpha \mathrm{V} \beta 3$ integrin, that binds to several ECM components present in bone tissues, including fibronectin, vitronectin, and osteopontin. Therefore, these tumor cells frequently form distant metastasis in these places (McCabe et al., 2007).

Experiments in which SSCs were transplanted into the seminiferous tubules of mice revealed the importance of these CAMs, particularly integrin $\beta 1$, in the spermatogonial cell homing process (Kanatsu-Shinohara et al., 2008). In these series of experiments spermatogonial cells isolated from $\beta 1$-integrin knockout animals were transplanted into wild type mice. Spermatogenesis and colonization of the niche by SSCs were analyzed at different periods of time and the results showed that cells lacking $\beta 1$-integrin had a significantly reduced colonization capacity (Kanatsu-Shinohara et al., 2008). Similarly, transplantation of spermatogonia into seminiferous tubules with $\beta 1$-integrin-deficient Sertoli cells showed as well impaired colonization, suggesting that these type of contacts might regulate germ cell movement during passage through the blood testis barrier.

As previously mentioned, PM cells constitute, together with the basement membrane, a physical barrier that provides structural support of the seminiferous tubules. In the last decades, it has been proven that PM cells regulate testicular homeostasis during testicular development and spermatogenesis (Mackay and Smith, 2007) being as well responsible for the formation of the basement membrane through the secretion of some of its main components together with other ECM proteins, such as fibronectin, laminin, collagens I, IV and XVIII, proteoglycans, entactin and osteonectin (also known as secreted protein acidic and rich in cysteine or SPARC) (Schell et al., 2008). In TGCTs, the basement membrane constitutes a physical barrier that prevents carcinoma cells to invade the stroma. Thus, deregulation of the secretory activity of PM cells might produce changes in the basement membrane composition that could be translated into less consistency and pro-migratory signals that would favor the progression from CIS to invasive TGCTs (Timmer et al., 1994). Platelet derived growth factor (PDGF) has been related with the origin and progression of TGCTs due to its role in angiogenesis and spermatogenesis, but more recently, its effect on PM cells has also been described, including stimulation of proliferation and the secretion of ECM proteins (Basciani et al., 2002).

PM cells are as well a source of pro-invasive factors associated with cell growth, differentiation, survival and migration to the reactive stroma in TGCTs. The secretory activity of this type of cell is complexly regulated by other components of the testicular microenvironment and the progression of intratubular germ cell tumors may cause changes in this secretory activity that could result in loss integrity of the basement membrane, which contribute to the tumor growth, invasion and metastasis of TGCTs (Díez-Torre et al., 2011). This disruption may result as well in changes of CAMs expression pattern and subsequently, in structural and functional disorders. Magnanti and colleagues (2001) examined the expression pattern and the role for integrins in the contraction activity of human and rat PMs. They showed that human PM cells express $\alpha 1, \alpha 2, \alpha 3, \alpha 5, \alpha 6, \alpha v, \beta 1, \beta 3$ and $\beta 4$ integrin subunits and intracellular adhesion molecule-1 (ICAM-1) and described in particular the role of $\beta 1$ integrin in cell contraction. Their results suggest that abnormal integrin pattern may promote alteration in the contractile activity, which may contribute to spermatogenic defect.

Concerning cell-cell adhesion, cadherin molecules are particularly interesting. The assembly and regulation of cohesive intercellular junctions is central to morphogenesis and tissue homeostasis, and calcium-dependent, transmembrane classical cadherins are the major architectural proteins at intercellular junctions (Leckband and Sivasankar. 2012). The adhesion mediated by these molecules is generally homophilic (cadherin-cadherin) and homotypic (between the same cell types), even though there are exceptions. Among the classic cadherin subfamily, the roles of E-cadherin, $\mathrm{N}$-cadherin and VE-cadherin have been mostly studied in human pluripotent stem cells. These three classical cadherins were originally named for the tissue in which they were prominently expressed: epithelial cadherin (E-cadherin) in skin epithelia, neural cadherin ( $\mathrm{N}$-cadherin) in the central nervous system and vascular endothelial cadherin (VE-cadherin) in blood vessel endothelia.

Interesting enougth E-cadherin and other cell adhesion molecules play a key role in survival and differentiation of human pluripotent stem cells. Recent studies of the mouse germline showed that expression of E-cadherin is localized to undifferentiated spermatogonia in the mouse testis including As, Apr, and Aal subtypes (Nakagawa et al., 2010). In cancer, a switch from E-cadherin to $\mathrm{N}$-cadherin expression leads to the epithelial-to-mesenchymal (EMT) transition and it is has been observed in hESC differentiation. Besides, loss of E-cadherin, a key component of adhesion junctions, is characteristic of EMT and it is associated with tumor cell invasion (Le Bras et al., 2012).

Regarding the neuronal cadherin, $\mathrm{N}$-cadherin (CDH2), the role of this $140 \mathrm{kD}$ protein in processes such as migration, differentiation, embryonic development and metastatic behavior of tumor cells has been reported. The analysis of the expression of cadherins in several stem cell types has demonstrated that, whereas ES cells only express E-cadherin, some teratocarcinoma-derived EC cell lines express both $\mathrm{E}$ - and $\mathrm{N}$-cadherin on their surface (Díez-Torre et al., 2004). In our laboratory, we have studied the function of Ecadherin in different ES and EC cell lines by aggregation assays in the presence and absence of specific anti-E-cadherin antibodies. We observed that all the analyzed cell lines were able to aggregate in the absence of antibodies. Nevertheless, the aggregation capacity of the PGC-derived EG-1 cell line and the ES cell line AB1 was totally abrogated by blocking E-cadherin, whereas this treatment did not significantly alter the aggregation ability of the two murine EC cell lines F9 and P19. These results indicate that at least in these cells, E-cadherin may not be essential for the aggregation process (Díez-Torre et al., 2004).

Recently, it has been found that down-regulation of $\mathrm{N}$-cadherin in malignant glioma results in cell polarization defects leading to abnormal motile behavior with increased cell speed and decreased persistence in directionality. Nevertheless, the role of cadherins in the development of cancer in non-epithelial tissues is still debated. This could be the case of TGCTs in which the aggressive embryonal carcinomas and chorionic carcinomas expression of $\mathrm{N}$-cadherin cannot be detected (Bremmer et al., 2012), unlike in the intratubular germ cell neoplasias, seminomas, teratomas and yolk sac tumors. 
Along with cadherins, the expression of dysadherin has been reported in testicular tumors. Dysadherin is a recently described cell membrane glycoprotein, which has an anti cell-cell adhesion function and down-regulates E-cadherin. Dysadherin is not expressed in non-neoplastic germ cells, neither in CIS or intratubular germ cell neoplasia, but it is highly expressed in all types of germ cell tumors. Since dysadherin is not normally expressed in non-neoplastic testis, it is conceivable that it plays a role in the neoplastic transformation of germ cells (Batistatou et al., 2005).

\section{Vascularization and hypoxia}

The blood vasculature of the testis conforms a highly organized system according to a pattern that is well conserved among mammals (Lupiañez et al., 2012). Two distinct orientation of vessels are found: those that run longitudinally, parallel to the seminiferous tubules, and the transverse ones, that surround the tubules and connect the longitudinal ones every 100 to $200 \mu \mathrm{m}$ (Silván et al., 2010 and Fig. 4). The term 'vascular niche' is used to refer to the microenvironment characterized by the presence of angiocrine factors and the ECM secreted by endothelial cells, which promotes the survival and proliferation of normal and malignant stem cells. Therefore, a close proximity of stem and endothelial cells to the blood capillaries is assumed. However, in the particular case of the mammalian testis, spermatogonia are separated from the blood vessels by a basal lamina and the SSC niche would therefore not strictly comply with the above assumption. Nevertheless, spermatogonia are not randomly spread along the seminiferous tubules and have a precise localization in the proximity of blood capillaries.
Using fluorescently labeled spermatogonia it was shown that the undifferentiated germ cells were preferentially found in portions of the basal compartment adjacent to blood vessels and particularly close to vessel branching points (Yoshida et al., 2007). Sertoli cells control another possible regulation of the oxygen concentration in the SSC niche. It is known that this cell type secretes Endothelin-1, a strong vasoconstrictor. Thus, by enhancing the secretion of this factor, the blood flow, and subsequently the oxygenation of the tissue, can be reduced. Considering that the Endothelin-1 receptors are variably expressed by the different germ cells (Maggi et al., 1995) it would be interesting to evaluate the availability of Endothelin-1 in the different stages of spermatogonial differentiation and determine which ones are associated with smooth muscle contraction.

As in most tumors, TGCTs vessel density is significantly increased in comparison to the normal tissue, however, the vascular architecture present in the testis is dramatically remodeled and transformed into a disorganized network with the characteristics of an immature vascular system (Silván et al., 2010). In experimental TGCTs generated by the transplantation of ES cells into the seminiferous tubules, the tumor vessels show irregular shapes, frequent compressions and blind endings (Silván et al., 2009a and Fig. 3). This chaotic vascular architecture results in defective oxygenation of the tumor tissue and hypoxic regions.

Cellular adaptation to hypoxia is mediated by the Hypoxia Inducible Factors (HIFs), being HIF-1 the best-characterized member of the family. This transcription factor is a heterodimer composed of a constitutively expressed $\beta$-subunit and an oxygen-regulated $\alpha$ subunit. In healthy tissues, functions of HIF-1 include the promotion
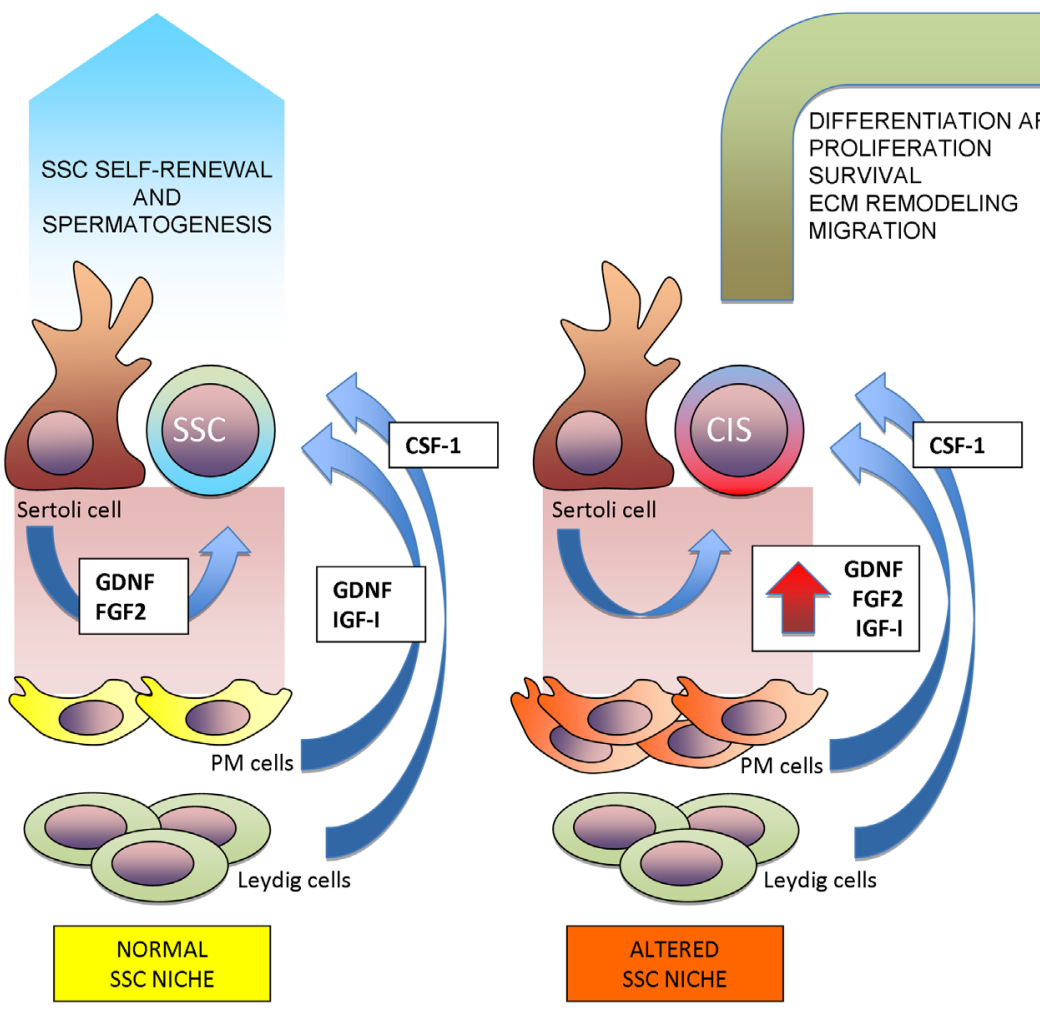
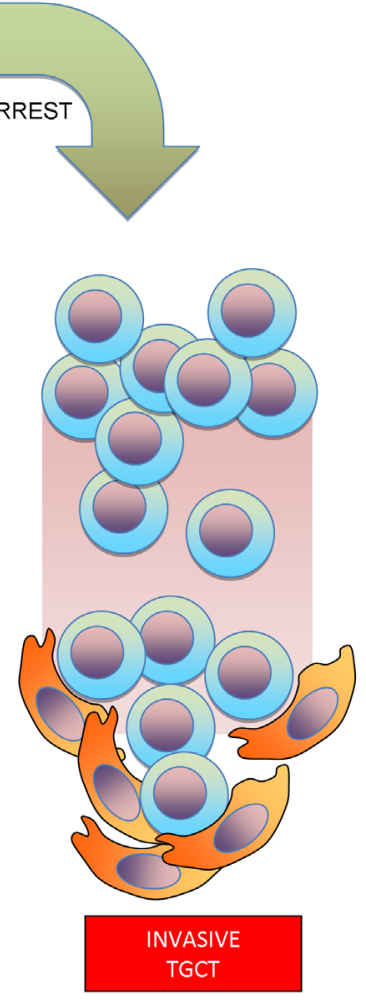

Fig. 4.The spermatogonial stem cell (SSC) niche and its potential implication in testicular germ cell tumor (TGCT) progression. Sertoli cells are key regulators of the microenvironment of the SSC niche, being the main source of the growth factors GDNF and FGF2, which regulate SSC proliferation and survival. Leydig cells secrete CSF-1, a specific regulator of SSC self-renewal. In humans, peritubular myoid cells have been reported to be a secondary source of GDNFand othergrowth factors that influence SSC proliferation and self-renewal, including IGF-I. In the presence of CIS of the testis, peritubular cells might respond to CIS-derived factors, including PDGF and TGF- $\beta$, increasing their proliferation and secretory activity. This could lead to the alteration of the SSC niche and increased expression of some of its determinants. Over-expression of GDNF has been related with TGCT development through the induction of differentiation arrest, proliferation and survival. IGF-I has been identified as an inductor of proteolytic enzymes that take part in remodeling of the extracellular matrix and as a key regulator of pro-migratory signals, such as the SDF-1/CXCR4 axis. Thus, any or all of these alterations of testis homeostasis could contribute to the development of invasive TGCTS. 
of vascularization and the coordination of the shift of the cells to anaerobic metabolism. In addition, it is known that reduced oxygenation levels can promote the undifferentiated state of many stem cell populations, including embryonic, hematopoietic, and neural stem cells among others. The role of hypoxia in the induction and maintenance of the pluripotent CSC phenotype has been proved as well in a number of different tumor types. However, in certain tumor types, an accumulation of CSCs in the proximity of vessels has been reported. Although this observation apparently opposes previous results, in vitro co-culture experiments have shown that endothelial cells secrete paracrine factors that promote CSC growth and stemness. Hence, endothelial cells might fulfill, besides their vascular role, other functions in the tumor tissue. In addition to the maintenance of stem cell characteristics, hypoxia alters the Notch1 signaling pathway and subsequently increases CSC proliferation and apoptosis resistance in other types of cancer. Furthermore, overlapping of pathways regulated by HIF and some oncogene signaling pathways, such as cMyc and p53, has been as well suggested as possible tumor promoting mechanism (Mazumdar et al., 2009). Regarding TGCTs, in vitro experiments in which ES and EC cell lines were cultured under hypoxic conditions, revealed that low oxygenation promoted faster proliferation, independently of the presence of LIF in the culture medium. In addition, expression of vasculogenic factors and endothelial markers, such as Placentallike Growth Factor (PIGF) or VEGF-A, together with endothelial cell markers was as well observed under low oxygenation cultures of ES cell lines (Silván et al., 2009b).

Expression of factors that promote vascularization has been described in a number of CSCs. In turn, experimental TGCTs show increased expression of factors related with vasculogenesis, such as VEGF-A and C, the VEGF receptors 1, 2 and 3, and PECAM-1 (Silván et al., 2010). Thus, it is possible that the undifferentiated cell population present in TGCTs takes advantage of the impaired blood supply and proliferates faster, originating, depending on the presence of additional growth factors, endothelial cells. In fact, transplantation of ES cells into the seminiferous tubules revealed their differentiation into endothelial cells that form part of the neoplastic vascular system (Silván et al., 2009a). Since the undifferentiated cell population of TGCTs has a differentiation potential comparable to that of ES cells (Aréchaga, 1993), it is likely that part of the vessels in spontaneous TGCTs as well arise from neoplastic cells. However, considering that EC cells cultured under hypoxic conditions did not express endothelial cell markers, it is feasible that this differentiation process requires additional factors (Silván et al., 2009b). Taken together, these characteristics result in the formation of a highly permeable vascular network, as revealed by the frequent extravasations of the injected resin in vascular corrosion casts (Silván et al., 2009a and Fig. 3). The leakiness of the vessels facilitates invasive tumor cells to enter the blood circulation and metastasize. Although most TGCTs and their metastases respond to chemotherapy, some patients with spread tumors are resistant to treatment. Remarkably, clinical studies establish a relationship between hypoxia and poor clinical outcome caused by increased metastasis and invasive potential (Vaupel, 2008).

During the last decades, a number of therapeutic targets have been proposed in order to control vasculogenesis and its consequences in cancer. Despite the efficacy of some of them in murine cancer models, the results of clinical trials in which anti-angiogenic agents were used together with chemotherapy have been disap- pointing (Kerbel, 2008). Since testicular cancer shows a high rate of metastasis, it represents a unique model to study this process. Furthermore, abetter understanding of the vascularization process and its implications in TGCTs is needed to develop new tools to combat tumor progression and to reduce the mortality associated with resistant and recurrent TGCT metastases. Abetter knowledge of the vasculogenic process in the testis would further improve the delivery of drugs to target sites in this and other malignancies.

\section{Mechanical stress and cytoskeletal organization in the spermatogonial niche and tumors}

The study of the mechanical microenvironment, as a player in normal stem cell differentiation and cancer has obtained increased attention during the last years. Although the role of the different mechanical features of the testicular tissue has never been precisely analyzed for the establishment of the SSC niche or in development of TGCTs, insights gained from other organs can throw some light on their importance. For example, using a 3D tubule system subjected to propel fluid flow, a situation that to certain extent reminds the seminiferous tubules, Huang and colleagues (2005) observed a differential fate of the seeded ES Flk+ cells depending on their location in this artificial system. While those cells on the luminal region expressed PECAM, and exhibited an endothelial phenotype, the cells found in the interstices among the artificial tubules expressed smooth muscle actin (SMA) and, therefore, reminded to the muscle cells surrounding the vessels (Huang et al., 2005). Similarly, shear stress applied to murine mesenchymal progenitor cells has shown to affect their morphology and enhance endothelial surface markers (Wang et al., 2005). In contrast, a variation on the stress parameters induces the differentiation of murine Flk+ ES cells into HSCs after a Runx1-triggered process.

Due to the similarities between CIS of the testis and ES cells, experiments in which stress is applied on the later may yield results significant for the study of testicular cancer. In a series of tests, in which magnetic twisting cytometry was used to locally apply tensile force on single murine ES cells, Chowdhury and colleagues (2010) observed a significant reduction in Oct3/4 expression, maintaining the surrounding non-stressed cells their undifferentiated state. Another mechanical characteristic crucial for stem cell differentiation is matrix stiffness. Engler and colleagues were the first to study the effect of substrates with different mechanical properties on stem cell lineage commitment. Their studies revealed that soft matrices mimic nervous tissues and are neurogenic, stronger matrices mimic muscle tissues and are myogenic, and rigid matrices are more similar to collagenous bone tissues being osteogenic (Engler et al., 2006).

Extensive ECM remodeling and stiffening characterizes malignant tissues. This is in part a result of an altered metabolism of collagen, which is the most abundant scaffolding protein in the stroma. In fact, increased collagen expression, deposition, and turnover have been directly related with tumor progression (Jodele et al., 2006). Although type I collagen has been considered a physical barrier that reduces tumor invasion, an increased expression of collagen is associated with elevated incidence of metastasis. It is as well known that collagen crosslinking and the resulting tissue fibrosis increase risk of malignancy (Colpaert et al., 2003). Since these results apparently contradict the correlation between high expression levels of MMPs and poor prognosis in cancer patients, 
it is possible that the underlying mechanism is more complex. Nevertheless, this interpretation could further explain the limited success of MMPs inhibitors in clinical trials. Another possible mechanism of stiffness regulation of malignancy involves enhanced integrin-dependent mechanotransduction.

In the testis, Sertoli cells are the only intratubular somatic cell in the seminiferous tubules and based on their proximity to undifferentiated spermatogonia, it is likely that they are directly involved in the establishment and maintenance of the adequate mechanical environment. As most mammalian cells, their cytoskeleton has three main components: actin, intermediate filaments (IFs) and microtubules (MTs). MTs are involved in maintaining the columnar shape of Sertoli cells, being however, the exact organization dependant of the developmental stage of spermatogenesis. For example, a marked increase in MTs in the cytoplasmic projections associated with round spermatids has been observed (Vogl, 1988). In general terms, like most epithelial cell types, Sertoli cells have a non-centrosomal MT organization with the MTs running along the long axis and with their minus ends oriented apically (Bartolini and Gundersen, 2006). Experiments using the MT disrupting drugs, such as colchicine, vinblastine or carbendazim resulted in a dramatic loss of Sertoli cell architecture as well as sloughing of germ cells (Correa et al., 2002).

The mechanical properties of IFs, combining flexibility and elasticity, together with their attachment to desmosome-like and hemidesmosome-like junctions, point to them as key players in the maintenance of tissue integrity, particularly in epithelial tissues. In Sertoli cells IFs mainly consist of vimentin (Franke et al., 1979), but keratins are expressed during testis development (Paranko et al., 1986). In normal testes, stromal cells and Leydig cells are as well positive for vimentin, while the epithelium lining the rete testis expresses cytokeratin. Although the vimentin knockout mouse is viable and the seminiferous epithelium in these animals looks remarkably normal (Colucci-Guyon et al., 1994) it is possible that in these cells IFs play a mechanical strengthening role only when the epithelium is stressed in a particular fashion or to sufficient levels. In testicular cancer, it has been reported that only a small part of the cells are positive for vimentin in seminomas (Miettinen et al., 1985). In some embryonal carcinomas vimentin-positive tumor cells were also found, probably representing either Sertoli cells trapped inside the malignant tissue or attempts to further differentiation of tumor cells. In addition, only a fraction of seminomas contain cytokeratin-positive cells, some of them multinucleated. In turn, tumor cells of embryonal carcinomas, endodermal sinus tumors and choriocarcinomas display cytokeratin positivity. In immature teratomas, both the immature and the mature epithelial components express cytokeratin, while the stromal components, including cartilage, contain vimentin, and the smooth-muscle elements, desmin (Miettinen et al., 1985).

$\mathrm{PM}$ cells might play as well an important role in the regulation of the mechanical conditions for the correct differentiation and self-renewal of spermatogonia. These cells that surround the seminiferous tubules are known to express cytoskeletal markers of smooth muscle cells ( $\alpha$-actin) and participate in the contraction of the seminiferous tubules for the propulsion of tubular fluid and spermatozoa (Wrobel et al., 1986). However, it was not until recently that the precise organization of their actin cytoskeleton has been revealed. Losinno and colleagues (2012) showed that these cells present an interconnected system of actin and myosin filament bundles distributed in two independent layers that are perpendicular to each other. Besides the steroid regulation of the contraction of the seminiferous tubules, Sertoli cells produce Endothelin-1, a potent stimulator of smooth muscle. There exist two types of receptors for Endothelin-1 in PM cells, named ET and $\mathrm{ET}_{\mathrm{B}}$, being probably each type of receptor responsible for the contraction in one direction. Thus, this system, triggered as well by Sertolicells, allows a precise mechanical regulation of the germinal epithelium and therefore may play a role in the generation of the forces needed for the correct maintenance and differentiation of the germinal stem cells.

High number of $\alpha$-actin expressing myofibroblasts in tumors has been associated with malignancy (Nakayama et al., 1998). Interestingly, in vitro experiments show that mechanical stiffness drives the myofibroblastic differentiation of some liver cells (Olsen et al., 2011). Since EC cells show high plasticity, part of the tumorassociated fibroblast might come from the malignant cells. In fact, in experimental TGCTs generated by transplantation of ES cells into the seminiferous tubules (Silván et al., 2011), the existence of a population of $\alpha$-actin positive cells derived from the tumor cells was as well described (Fig. 3D; Diez-Torre et al., 2011). Furthermore, mechanical stress, especially compressive strains, which could be equivalent to the high pressures caused by defective TGCT vascularization (Figs. 3E and 3F), promotes expression of smooth muscle cell-specific cytoskeletal protein in marrow stromal cells. Nevertheless, the precise role of PM cells in the establishment of the stem cell niche and in TGCTs development remains an open question. It would be therefore interesting to analyze the effect of relaxation and permanent contraction of these cells on stem cell differentiation and progression of CIS into invasive carcinoma.

\section{Conclusions}

Understanding the microenvironment in which tissue stem cell populations are maintained becomes increasingly important. The wide knowledge of male germ cell differentiation, together with the existence of several animal mutants that show deficiencies in spermatogenesis, make SSCs a unique model for the study of the adult stem cell niche of spermatogia and its malignant transformation. Additionally, several techniques that have been specifically developed for the functional study of testis are useful in the study of the referred microenvironment. These include transplantation of different cell types, such as somatic, embryonic, tumorigenic and germinal cells into the seminiferous tubules, and direct modification of the cells forming the germinal epithelium. However, the acquired knowledge of the different components that define the niche should be studied integrated to positively understand their significance. Furthermore, considering that many of the molecular pathways involved in stem cell maintenance are shared by the malignant cancer stem cells, some of them might represent novel targets for cancer therapy.

\section{Acknowledgements}

This work was supported by Grants from the Spanish Ministry of Economy and Competitivity (SAF2012-39773), Basque Regional Government (IT56010) and the SPRI/Saiotek program of the Basque Society for Industrial Restructuring and Promotion (S-OA11UN001). The authors would like to thank to Mr. Juan Luis Vidaurrazaga and Dr. David Fogarty for his editorial assistance. Pablo Moreno had a predoctoral fellowship from the Jesús de Gangoiti Barrera Foundation (Bilbao, Vizcaya, Spain). 


\section{References}

ARÉCHAGA J (1993). On the boundary between development and neoplasia. An interview with Professor G. Barry Pierce. Int J Dev Biol 37: 5-16.

BARTOLINI, F., and GUNDERSEN, G.G. (2006). Generation of noncentrosomal microtubule arrays. J Cell Sci 119: 4155-4163.

BASCIANI, S., MARIANI, S., ARIZZI, M., ULISSE, S., RUCCI, N., JANNINI, E.A., DELLA ROCCA, C., MANICONE, A., CARANI, C., SPERA, G., and GNESSI, L. (2002). Expression of platelet-derived growth factor-A (PDGF-A), PDGF-B, and PDGF receptor-alpha and -beta during human testicular development and disease. J Clin Endocrinol Metab 87: 2310-2319.

BATISTATOU, A., SCOPA, C.D., RAVAZOULA, P., NAKANISHI, Y., PESCHOS, D., AGNANTIS, N.J., HIROHASHI, S., and CHARALABOPOULOS, K.A. (2005). Involvement of dysadherin and $\mathrm{E}$-cadherin in the development of testicular tumours. Br J Cancer 93: 1382-1387.

BLAGOEV, K.B. (2011). Organ aging and susceptibility to cancer may be related to the geometry of the stem cell niche. Proc Natl Acad Sci USA 108: 19216-19221.

BLOCH, W., FORSBERG, E., LENTINI, S., BRAKEBUSH, C., MARTIN, K., KRELL, H.W., WEIDLE, U.H., ADDICKS, K., and FÄSSLER, R. (1997). $\beta 1$ integrin is essential for teratoma growth and angiogenesis J Cell Biol 139: 265-278.

BONAFÈ, M., STORCI, G., and FRANCESCHI, C. (2012). Inflamm-aging of the stem cell niche: breast cancer as a paradigmatic example: breakdown of the multi-shell cytokine network fuels cancer in aged people. Bioessays 34: 40-49.

BREMMER, F., HEMMERLEIN, B., STRAUSS, A., BURFEIND, P., THELEN, P., RADZUN, H.J., and BEHNES, C.L. (2012). N-cadherin expression in malignant germ cell tumours of the testis. BMC Clin Pathol 12: 19.

CAVEL, O., SHOMRON, O., SHABTAY, A., VITAL, J., TREJO-LEIDER, L., WEIZMAN, N., KRELIN, Y., FONG, Y., WONG, R.J., AMIT, M., and GIL, Z. (2012). Endoneurial Macrophages Induce Perineural Invasion of Pancreatic Cancer Cells by Secretion of GDNF and Activation of RET Tyrosine Kinase Receptor. Cancer Res 72: 5733-5743.

CHEVAliER, N., BARLIER, A., ROCHE, C., MOGRABI, B., CAMPARO, P., DEVOUASSOUX-SHISHEBORAN, M., MICHIELS, J.F., NEBOUT, M., CHEVALLIER, D., BENAHMED, M., ENJALBERT, A., and FÉNICHEL, P. (2010). RET gene mutations are not involved in the origin of human testicular seminoma. Int $J$ Androl 33: 848-852.

CHOWDHURY, F., NA, S., LI, D., POH, Y.C., TANAKA, T.S., WANG, F., and WANG, N. (2010). Material properties of the cell dictate stress-induced spreading and differentiation in embryonic stem cells. Nat Mater 9: 82-88.

CLIFFORD, A., LOWELL, M.D., and TANYA, N.M. (2012). Overview-studying integrins in vivo. Methods Mol Biol 757: 369-397.

CONIGLIO, S.J., EUGENIN, E., DOBRENIS, K., STANLEY, E.R., WEST, B.L., SYMONS, M.H., and SEGALL, J.E. (2012). Microglial stimulation of glioblastoma invasion involves epidermal growth factor receptor (EGFR) and colony stimulating factor 1 receptor (CSF-1R) signaling. Mol Med 18: 519-527.

CONDEELIS, J., and POLLARD, J.W. (2006). Macrophages: obligate partners for tumor cell migration, invasion and metastasis. Cell 124: 263-266.

COLPAERT, C.G., VERMEULEN, P.B., FOX, S.B., HARRIS, A.L., DIRIX, L.Y., and VAN MARCK, E.A. (2003). The presence of a fibrotic focus in invasive breast carcinoma correlates with the expression of carbonic anhydrase IX and is a marker of hypoxia and poor prognosis. Breast Cancer Res Treat 81: 137-147.

COLUCCI-GUYON, E., PORTIER, M.M., DUNIA, I., PAULIN, D., POURNIN, S., and BABINET, C. (1994). Mice lacking vimentin develop and reproduce without an obvious phenotype. Cell 79: 679-694.

CONBOY, I.M., CONBOY, M.J., WAGERS, A.J., GIRMA, E.R., WEISSMAN, I.L., and RANDO, T.A. (2005). Rejuvenation of aged progenitor cells by exposure to a young systemic environment. Nature 433: 760-764.

CORREA, L.M., NAKAI, M., STRANDGAARD, C.S., HESS, R.A., and MILLER, M.G. (2002). Microtubules of the mouse testis exhibit differential sensitivity to the microtubule disruptors Carbendazim and colchicine. Toxicol Sci69: 175-182.

DÍEZ-TORRE, A., SILVÁN, U., DE WEVER, O., BRUYNEEL, E., MAREEL, M., and ARÉCHAGA, J. (2004). Germinal tumor invasion and the role of the testicular stroma. Int J Dev Biol 48: 682-690.

DÍEZ-TORRE, A., SILVÁN, U., DÍAZ-NÚÑEZ, M., and ARÉCHAGA, J. (2010). The role of microenvironment in testicular germ cell tumors. Cancer Biol Ther 10: 529-536.
DÍEZ-TORRE, A., SILVÁN, U., MORENO, P., GUMUCIO, J., and ARÉCHAGA, J (2011). Peritubular myoid cell-derived factors and its potential role in the progression of testicular germ cell tumours. Int J Androl 34: e252-264.

DRESCHER, B., LAUKE, H., HARTMANN, M., DAVIDOFF, M.S., and ZUMKELLER, W. (1997). Immunohistochemical pattern of insulin-like growth factor (IGF) I, IGF II and IGF binding proteins 1 to 6 in carcinoma in situ of the testis. Mol Pathol 50: 298-303.

ENGLER, A.J., SEN, S., SWEENEY, H.L., and DISCHER, D.E. (2006). Matrix elasticity directs stem cell lineage specification. Cell 126: 677-689.

FERRANTI, F., MUCIACCIA, B., RICCI, G., DOVERE, L., CANIPARI, R., MAGLIOCCA F., STEFANINI, M., CATIZONE, A., and VICINI, E. (2012). Glial cell line-derived neurotrophic factor promotes invasive behaviour in testicular seminoma cells. Int J Androl 35:758-768.

FRANKE, W.W., GRUND, C., and SCHMID, E. (1979). Intermediate-sized filaments present in Sertoli cells are of the vimentin type. Eur J Cell Biol 19: 269-275

FROMENT, P., VIGIER, M., NEGRE, D., FONTAINE, I., BEGHELLI, J., COSSET, F.L., HOLZENBERGER, M., and DURAND, P. (2007). Inactivation of the IGF-I receptor gene in primary Sertoli cells highlights the autocrine effects of IGF-I. J Endocrinol 194: 557-568

FUJIMOTO, H., SANGAI, T., ISHII, G., IKEHARA, A., NAGASHIMA, T., MIYAZAKI, M., and OCHIAI, A. (2009). Stromal MCP-1 in mammary tumors induces tumorassociated macrophage infiltration and contributes to tumor progression. Int $\mathrm{J}$ Cancer 125: 1276-1284

FURUTA, A., FUNAHASHI, H., SAWAI, H., SATO, M., OKADA, Y., TAKEYAMA, H., and MANABE, T. (2007). The relationship between GDNF and integrins in human colorectal cancer cell activity. Hepatogastroenterology 54: 1398-1402.

HOEI-HANSEN, C.E., RAJPERT-DE MEYTS, E., DAUGAARD, G., and SKAKKEBAEK, N.E. (2005). Carcinoma in situ testis, the progenitor of testicular germ cell tumours: a clinical review. Ann Oncol 16: 863-868.

HUANG, Y.H., CHIN, C.C., HO, H.N., CHOU, C.K., SHEN, C.N., KUO, H.C., WU, T.J., WU, Y.C., HUNG, Y.C., CHANG, C.C., and LING, T.Y. (2009). Pluripotency of mouse spermatogonial stem cells maintained by IGF-1-dependent pathway. FASEB J 23: 2076-2087.

HUANG, H., NAKAYAMA, Y., QIN, K., YAMAMOTO, K., ANDO, J., YAMASHITA, J., ITOH, H., KANDA, K., YAKU, H., OKAMOTO, Y., and NEMOTO, Y. (2005). Differentiation from embryonic stem cells to vascular wall cells under in vitro pulsatile flow loading. J Artif Organs 8: 110-118.

JIA, D., ENTERSZ, I., BUTLER C., and FOTYR.A. (2012). Fibronectin matrix-mediated cohesion suppresses invasion of prostate cancer cells. BMC Cancer 12: 94.

JODELE, S., BLAVIER, L., YOON, J.M., and DECLERCK, Y.A. (2006). Modifying the soil to affect the seed: role of stromal-derived matrix metalloproteinases in cance progression. Cancer Metastasis Rev 25: 35-43.

KANATSU-SHINOHARA, M., INOUE, K., OGONUKI, N., MIKI, H., and YOSHIDA S. (2007). Leukemia inhibitory factor enhances formation of germ cell colonies in neonatal mouse testis culture. Biol Reprod 76: 55-62.

KANATSU-SHINOHARA, M., TAKEHASHI, M., TAKASHIMA, S., LEE, J., MORIMOTO H., CHUMA, S., RADUCANU, A., NAKATSUJI, N., FÄSSLER, R., and SHINOHARA, T. (2008). Homing of mouse spermatogonial stem cells to germline niche depends on beta1-integrin. Cell Stem Cell 3: 533-542.

KERBEL, R.S. (2008). Tumor angiogenesis. N Engl J Med 358: 2039-2049.

KUBOTA, H., AVARBOCK, M.R., and BRINSTER, R.L. (2004). Growth factors essential for self-renewal and expansion of mouse spermatogonial stem cells. Proc Natl Acad Sci USA 101: 16489-16494.

LE BRAS, G.F., TAUBENSLAG, K.J., and ANDL, C.D. (2012). The regulation of cell-cell adhesion during epithelial-mesenchymal transition, motility and tumor progression. Cell Adh Migr 6: 365-373.

LECKBAND, D., and SIVASANKAR, S. (2012). Cadherin recognition and adhesion. Curr Opin Cell Biol 24: 620-627.

LEE, J., KANATSU-SHINOHARA, M., INOUE, K., OGONUKI, N., and MIKI, H. (2007). Akt mediates self-renewal division of mouse spermatogonial stem cells. Development 134: 1853-1859.

LOSINNO, A.D., MORALES, A., FERNÁNDEZ, D., and LOPEZ, L.A. (2012). Peritubular myoid cells from rat seminiferous tubules contain actin and myosin filaments distributed in two independent layers. Biol Reprod 86: 1-8.

LUPIAÑEZ, D.G., REAL, F.M., DADHICH, R.K., CARMONA, F.D., BURGOS, M., 
BARRIONUEVO, F.J., and JIMÉNEZ, R. (2012). Pattern and density of vascularization in mammalian testes, ovaries, and ovotestes. J Exp Zool B Mol Dev Evo 318: 170-181.

MACKAY, S., and SMITH, R.A. (2007). Effects of growth factors on testicular morphogenesis. Int Rev Cytol 260: 113-173.

MAGGI, M., BARNI, T., ORLANDO, C., FANTONI, G., FINETTI, G., VANNELLI, G.B., MANCINA, R., GLORIA, L., BONACCORSI, L., YANAGISAWA, M., and FORTI, G. (1995). Endothelin-1 and its receptors in human testis. J Androl 16: 213-224.

MAGNANTI, M., GISMONDI, A., GANDINI, O., ROSSI, F.M., MICHETTI, P.M., SANTIEMMA, V., and MORRONE, S. (2001). Integrin Pattern and Effect on Contraction in Cultured Testicular Peritubular Myoid Cells. AJRI 45: 21-27.

MAZUMDAR, J., DONDETI, V., and SIMON, M.C. (2009). Hypoxia-inducible factors in stem cells and cancer. J Cell Mol Med 13: 4319-4328.

McCABE, N.P., DE, S., VASANJI, A., BRAINARD, J., and BYZOVA, T.V. (2007). Prostate cancer specific integrin $\alpha v \beta 3$ modulates bone metastatic growth and tissue remodeling. Oncogene 26: 6238-6243.

MENG, X., LINDAHL, M., HYVÖNEN, M.E., PARVINEN, M., and DE ROOIJ, D.G. (2000). Regulation of cell fate decision of undifferentiated spermatogonia by GDNF. Science 287: 1489-1493.

MIETTINEN, M., VIRTANEN, I., and TALERMAN, A. (1985). Intermediate filament proteins in human testis and testicular germ-cell tumors. Am J Pathol 120:402-410.

MULLANEY, B.P., and SKINNER, M.K. (1992). Basic fibroblast growth factor (bFGF) gene expression and protein production during pubertal development of the seminiferous tubule: folliclestimulating hormone-induced Sertoli cell bFGF expression. Endocrinology 131: 2928-2934.

NAGANO, M., RYU, B.Y., BRINSTER, C.J., AVARBOCK, M.R., and BRINSTER, R.L. (2003). Maintenance of mouse male germ line stem cells in vitro. Biol Reprod 68: 2207-2214.

NAKAYAMA, H., ENZAN, H., MIYAZAKI, E., NARUSE, K., KIYOKU, H., and HIROI, M. (1998). The role of myofibroblasts at the tumor border of invasive colorectal adenocarcinomas. Jpn J Clin Oncol 28: 615-620.

NAKAGAWA, T., SHARMA, M., NABESHIMA, Y., BRAUN, R.E., and YOSHIDA, S. (2010). Functional hierarchy and reversibility within the murine spermatogenic stem cell compartment. Science 328: 62-67.

OATLEY J M and BRINSTER R L (2008) Regulation of spermatogonial stem cell self-renewal in mammals. Ann Rev Cell Dev Biol 24: 263-286

OATLEY J M and BRINSTER R L (2012) The germline stem cell niche unit in mammalian testes. Physiol Rev 92: 577-595

OATLEY, J.M., OATLEY, M.J., AVARBOCK, M.R., TOBIAS, J.W., and BRINSTER, R.L. (2009). Colony stimulating factor 1 is an extrinsic stimulator of mouse spermatogonial stem cell self-renewal. Development 136: 1191-1199.

OLSEN, A.L., BLOOMER, S.A., CHAN, E.P., GAÇA, M.D., GEORGES, P.C., SACKEY, B., UEMURA, M., JANMEY, P.A., and WELLS, R.G. (2011). Hepatic stellate cells require a stiff environment for myofibroblastic differentiation. Am J Physiol Gastrointest Liver Physiol 301: 110-118.

OOSTERHUIS J W and LOOIJENGA L H (2005) Testicular germ-cell tumors in a broader perspective. Nat Rev Cancer 5: 210-222.

PARANKO, J., KALLAJOKI, M., PELLINIEMI, L.J., LEHTO, V.P., and VIRTANEN, I. (1986). Transient coexpression of cytokeratin and vimentin in differentiating rat Sertoli cells. Dev Biol 117: 35-44.

PYONTECK, S.M., GADEA, B.B., WANG, H.W., GOCHEVA, V., HUNTER, K.E., TANG, L.H., and JOYCE, J.A. (2012). Deficiency of the macrophage growth factor CSF-1 disrupts pancreatic neuroendocrine tumor development. Oncogene31:1459-1467.

RAJPERT-DE MEYTS, E. (2006). Developmental model for the pathogenesis of testicular carcinoma in situ: genetic and environmental aspects. Hum Reprod Update 12: 303-323.

SCHELL, C., ALBRECHT, M., MAYER, C., SCHWARZER, J.U., FRUNGIERI, M.B., and MAYERHOFER, A. (2008). Exploring human testicular peritubular cells: identification of secretory products and regulation by tumor necrosis factor-alpha. Endocrinology 149: 1678-1686.

SCHOFIELD, R. (1978). The relationship between the spleen colony-forming cell and the haemopoietic stem cell. Blood Cells 4: 7-25.

SCHLUETER, P.J., SANG, X., DUAN, C., and WOOD, A.W. (2007). Insulin-like growth factor receptor $1 \mathrm{~b}$ is required for zebrafish primordial germ cell migration and survival. Dev Biol 305: 377-387.
SILVAN, U., and ARECHAGA, J. (2012). Anatomical basis for cell transplantation into mouse seminiferous tubules. Reproduction 144: 385-392.

SILVÁN, U., DÍEZ-TORRE, A., ANDRADE, R., ARLUZEA, J., SILIÓ, M., and ARÉCHAGA, J. (2011). Embryonic stem cell transplantation into seminiferous tubules: a model for the study of invasive germ cell tumors of the testis. Cell Transplant 20: 637-642.

SILVÁN, U., ARLUCEA, J., ANDRADE, R., DÍEZ-TORRE, A., SILIÓ, M., KONERDING, M.A., and ARÉCHAGA, J. (2009a). Angiogenesis and vascular network of teratocarcinoma from embryonic stem cell transplant into seminiferous tubules. Br J Cancer 101: 64-70.

SILVÁN, U., DÍEZ-TORRE, A., ARLUZEA, J., ANDRADE, R., SILIÓ, M., and ARÉCHAGA, J. (2009b). Hypoxia and pluripotency in embryonic and embryonal carcinoma stem cell biology. Differentiation 78: 159-168.

SILVÁN, U., DÍEZ-TORRE, A., JIMÉNEZ-ROJO, L., and ARÉCHAGA, J. (2010). Vascularization of testicular germ cell tumours: evidence from experimental teratocarcinomas. Int J Androl 33: 765-774.

SPINNLER, K., KÖHN, F.M., SCHWARZER, U., and MAYERHOFER, A. (2010). Glial cell line-derived neurotrophic factor is constitutively produced by human testicular peritubular cells and may contribute to the spermatogonial stem cell niche in man. Hum Reprod 25: 2181-2187.

SU, C.M., LU, D.Y., HSU, C.J., CHEN, H.T., HUANG, C.Y., YANG, W.H., SU, Y.C., YANG, S.N., FONG, Y.C., TSENG, W.P., and TANG, C.H. (2009). Glial cell-derived neurotrophic factor increases migration of human chondrosarcoma cells via ERK and NF-kappaB pathways. J Cell Physiol 220: 499-507.

SUZUKI, H., SADA, A., YOSHIDA, S., and SAGA, Y. (2009). The heterogeneity of spermatogonia is revealed by their topology and expression of marker proteins including the germ cell-specific proteins Nanos2 and Nanos3. Dev Biol 336 222-231.

TADOKORO, Y., YOMOGIDA, K., OHTA, H., TOHDA, A., and NISHIMUNE, Y. (2002). Homeostatic regulation of germinal stem cell proliferation by the GDNF/FSH pathway. Mech Dev 113: 29-39.

TAVERNA, D., and HYNES, R.O. (2001). Reduced blood vessel formation and tumor growth in alpha5-integrin-negative teratocarcinomas and embryoid bodies. Cancer Res 61: 5255-5261.

TIMMER, A., OOSTERHUIS, J.W., SCHRAFFORDT KOOPS, H., SLEIJFER, D.T., SZABO, B.G., and TIMENS, W. (1994). The tumor microenvironment: possible role of integrins and the extracellular matrix in tumor biological behaviour of intratubular germ cell neoplasia and testicular seminomas. Am J Pathol 144: 1035-1044.

VANNELLI, B.G., BARNI, T., ORLANDO, C., NATALI, A., SERIO, M., and BALBONI, G.C. (1988). Insulin-like growth factor-I (IGF-I) and IGF-I receptor in human testis: an immunohistochemical study. Fertil Steril 49: 666-669.

VAUPEL, P. (2008). Hypoxia and aggressive tumor phenotype: implications for therapy and prognosis. Oncologist 13: 21-26.

VOGL, A.W. (1988). Changes in the distribution of microtubules in rat Sertoli cells during spermatogenesis. Anat Rec 222: 34-41.

VOGL, A.W., VAID, K.S., and GUTTMAN, J.A. (2008). The Sertoli cell cytoskeleton. Adv Exp Med Biol 636: 186-211.

WAN, G., and TOO, H.P. (2010). A specific isoform of glial cell line-derived neurotrophic factor family receptor alpha 1 regulates RhoA expression and glioma cell migration. J Neurochem 115: 759-70.

WANG, H., RIHA, G.M., YAN, S., LI, M., CHAI, H., YANG, H., YAO, Q., and CHEN, C. (2005). Shear stress induces endothelial differentiation from a murine embryonic mesenchymal progenitor cell line. Arterioscler Thromb Vasc Biol 25: 1817-1823.

WILSON, M.J., BOWLES, J., and KOOPMAN, P. (2006). The matricellular protein SPARC is internalized in Sertoli, Leydig, and germ cells during testis differentiation. Mol Reprod Dev 73: 531-539.

WONG, C.W, DYE, D.E., and COOMBE, D.R. (2012). The role of immunoglobulin superfamily cell adhesion molecules in cancer metastasis. Int J Cell Biol 2012 340296 (doi: 10.1155/2012/340296).

WROBEL, K.H., SCHILLING, E., and ZWACK, M. (1986). Postnatal development of the connexion between tubulus seminiferous and tubulus rectus in the bovine testis. Cell Tissue Res 246: 387-400.

YOSHIDA, S., SUKENO, M., and NABESHIMA, Y. (2007). A vasculature-associated niche for undifferentiated spermatogonia in the mouse testis. Science 317: $1722-1726$. 


\section{Further Related Reading, published previously in the Int. J. Dev. Biol.}

Regulation of primordial germ cell development in the mouse

M De Felici

Int. J. Dev. Biol. (2000) 44: 575-580

Developmental fates of the mouse germ cell line

Y Matsui

Int. J. Dev. Biol. (1998) 42: 1037-1042

The germ cell--the mother of all stem cells

P J Donovan

Int. J. Dev. Biol. (1998) 42: 1043-1050

Teratocarcinoma: neoplastic lessons about normal embryogenesis

I Damjanov

Int. J. Dev. Biol. (1993) 37: 39-46

Ontogeny, pathology, oncology

V E Papaioannou

Int. J. Dev. Biol. (1993) 37: 33-37

Extrinsic factors in cellular differentiation

R L Gardner

Int. J. Dev. Biol. (1993) 37: 47-50

Regulators of normal development and tumor suppression

L Sachs

Int. J. Dev. Biol. (1993) 37: 51-59

Understanding the roles of growth factors in carcinogenesis: modulation of autocrine growth control by differentiation

A Rizzino

Int. J. Dev. Biol. (1993) 37: 61-65

5 yr ISI Impact Factor $(2011)=2.959$
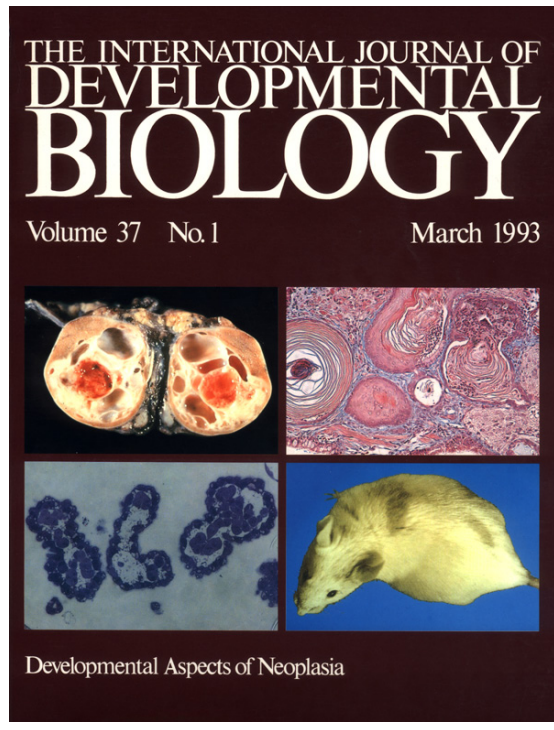

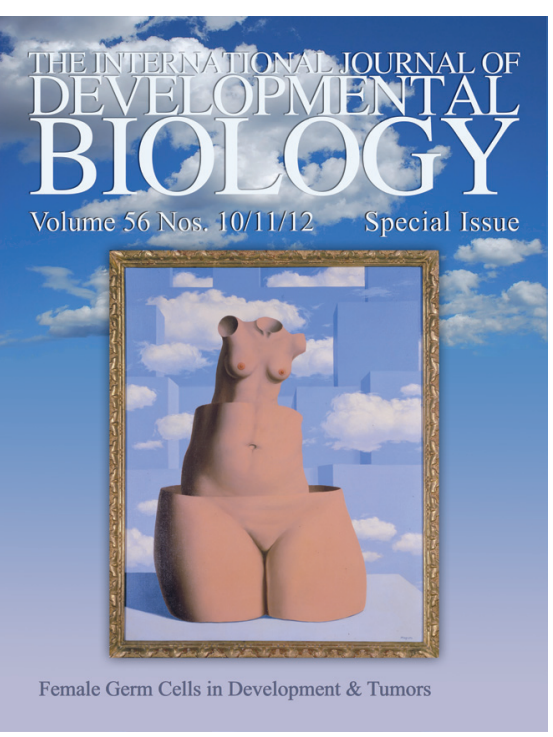

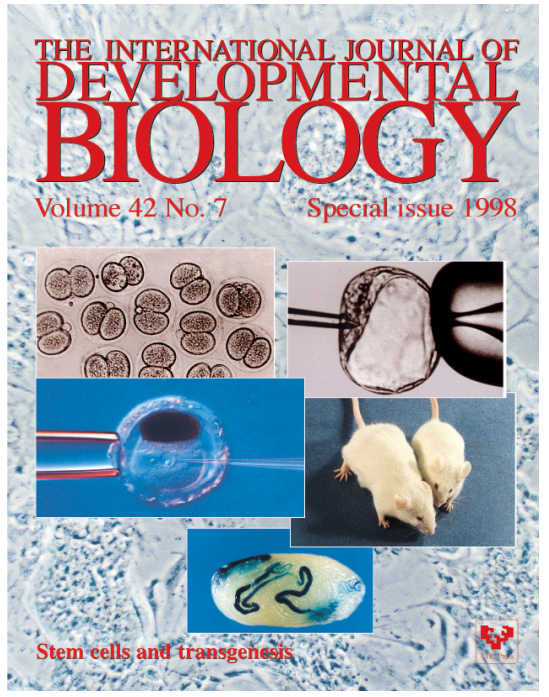

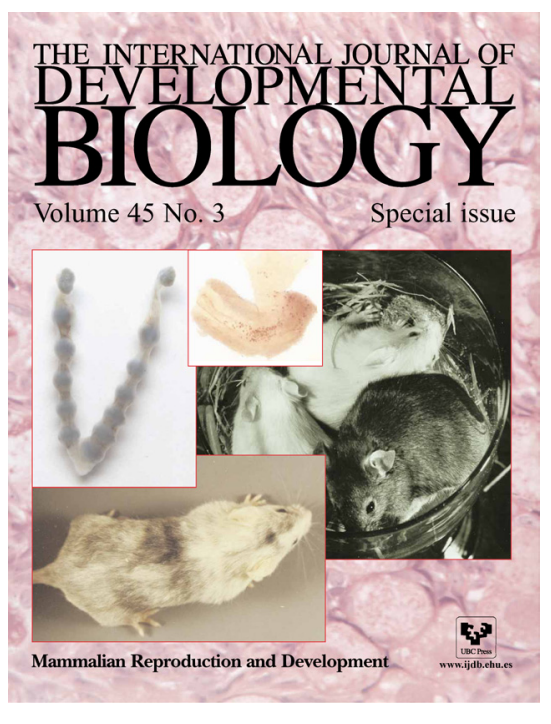

